\title{
ДОСВІД ФОРМУВАННЯ ПСИХОЛОГІЧНОЇ ГОТОВНОСТІ МАЙБУТНЬОГО ЛІКАРЯ ДО ПРОФЕСІЙНОЇ ДІЯЛЬНОСТІ
}

\section{Сміла Наталія Володимирівна}

Науковий кореспондент лабораторії психологіі навчання Інституту психології імені Г.С. Костюка НАПН Украӥни, м. Київ (Украӥна)

\section{Лазуренко Олена Олексї̈на}

Старший викладач кафедри загальної $і$ медичної психології та педагогіки Начіонального медичного університету імені О.О. Богомольия, м. Київ (Україна)

\begin{abstract}
Анотація. $У$ статті розглянуто особливості формування психологічної готовності майбутнього лікаря до професійної діяльності. Представлена авторська програма розвитку психологічної готовності до майбутньої діяльності на різних етапах професійної підготовки у вищому медичному навчальному закладі. В роботі обтрунтовано основні стадіі становлення психологічної готовності до професійної діяльності з урахуванням основних вікових особливостей майбутніх фахівців. Зокрема виділено стадї: вибір професії, вступ у навчання, адаптація до навчання, адаптація до професійної діяльності. Розроблено структуру психологічної готовності лікаря до здійснення професійної діяльності, щуо включила в себе такі шість компонентів: професійно-інтелектуальний, комунікативний, емоиійно-вольовий, моральний, динамічний, нервово-психічний. Виділено психолого-педагогічні складові формування психологічної готовності майбутнього лікаря у навчальному процесі. Запропонована програма формування психологічної готовності майбутнього лікаря до професійної діяльності. Викладено загальну стратегію, структуру, розкриті методичні підходи та рекомендації програми, спрямованої на формування психологічної готовності студентів - майбутніх лікарів до професійної діяльності. Зроблено висновки та сформовано перспективи подальших наукових досліджень.
\end{abstract}

Ключові слова: професійна діяльність, психологічна готовність, професійне становлення лікаря, професійна компетентність, особистісний розвиток, професійна підготовка.

Постановка проблеми та їі зв'язок 3 охороною здоров'я важливе місце займає псиважливими практичними завданнями. Се- хологічна підготовка медичних кадрів. У найред невідкладних завдань, які стоять перед ближчому майбутньому сьогоднішні студен- 
ти-медики будуть активно працювати і безпосередньо контактувати 3 людьми. Хоча взаємодія пацієнта 3 лікарем являє собою лише один з багатьох аспектів у лікуванні, неможливо заперечити, що якість цієї взаємодії є дуже важливою для пацієнтів. В таких умовах суттєво підвищуються вимоги до лікарів як до фахівців, що здатні не тільки ефективно виконувати професійні обов'язки, а й виступати в ролі провідників високих моральних цінностей та стандартів міжособистісної поведінки.

Цілеспрямований розвиток психологічної готовності майбутнього лікаря означає спрямованість освіти не тільки на формування знань, вмінь та навичок, а й на багаторівневий розвиток індивідуально-психологічних властивостей, здібностей, розширення можливостей застосування творчості майбутніх фахівців у сфері медицини. Саме багатогранний особистісний розвиток забезпечить більш повне розкриття професійно значущих вмінь та можливість ефективного виконання професійних обов'язків і функцій у майбутньому.

Аналіз останніх досліджень і публікацій. Проблему психологічної готовності майбутнього фахівця до професійної діяльності неодноразово розглядали 3 теоретичних та експериментальних позицій вітчизняні та зарубіжні дослідники: О. Ф. Генов, М. І. Д'яченко, С. Л. Жук, Л. А. Кандибович, О. Д. Кудрін, Н. В. Кузьміна, М. В. Левченко, С. Д. Максименко, В. О. Моляр, О. Г. Мороз, С. С. Салаватова, В. А. Сластьонін, Л. І. Федорова; спе- цифіці діяльності медичного працівника та його особистості присвячені роботи I. С. Вітенко, Н. С. Головньова, М. І. Жукова, В. Ю. Каган, Т. П. Кондратенко, В. П. Лавренко, В. К. Мягер, В. І. Ораховський, О. І. Орлов, Л. М. Супрун, В. О. Ташликов, Б. О. Федоришин; аналізу процесу становлення фахівця присвячені роботи М. О. Будзяк, Т. Гіббса, Л. В. Дудікової, І. А. Коваль, К. С. Максименко, С. Д. Максименка, М. В. Папучі, Н. В. Чепелєвої. Не зважаючи, на здавалось би, глибоке дослідження питання професійного розвитку медичного працівника, маємо констатувати, що ще й досить залишаються не уточненими компоненти психологічної готовності майбутнього лікаря до професійної діяльності та фактори їх формування на різних етапах професійного становлення.

В ході аналізу наукових підходів до визначення поняття готовності до діяльності були виявлені деякі суттєві відмінності в поглядах вітчизняних та зарубіжних вчених. Погляди вітчизняних науковців (I. А. Ендеберк, I. А. Зязюн, А. Ф. Ліненко, С. А. Литвиненко, С. Д. Максименко, Ю. В. Пелех, Н. М. Петрученко, Л. 3. Сердюк) грунтуються на діяльнісному підході, згідно якому готовність розглядається як інтегративна характеристика особистості, що грунтується на наявності у людини професійно значущих якостей, знань, умінь та навичок, цілей, мотивів та цінностей. Визначальною рисою вітчизняної школи є те, що готовність до діяльності не ототожнюється 3 
компетентністю.

Зарубіжна система поглядів, що відображена в роботах європейських (Р. Балтусайте, Т. Бурдон, І. Катане, П. Мідоус, Л. Мілвард, Д. Хьюстон) та північноамериканських (Л. Арнольд, Т. К. Біксон, Д. Бок, С. А. Лоу, М. С. Найер, М. Шафер) науковців, більше схиляється до розгляду компетентності як необхідного та базового складника психологічної готовності до діяльності. Наряду 3 компетентністю важливим компонентом виступають професійно важливі якості, що проявляються в сфері спілкування, взаємодії та вирішенні професійних завдань. При цьому обидва компоненти, і компетентнісний, і особистісний, є рівно значущими.

Виділення невирішених раніше частин загальної проблеми, якій присвячусться стаття. На наш погляд, недостатня визначеність базових понять теми дослідження, висока суспільна потреба в якісних медичних кадрах, недостатність дослідження проблеми психологічної готовності лікаря до професійної діяльності та критеріїв іiі сформованості обумовили актуальність теми дослідження. Крім того, необхідно знайти такий підхід, вибудувати таку програму, яка зможе забезпечити розвиток індивідуальності фахівця, зокрема формування його психологічної готовності до професійної діяльності протягом всього процесу навчання у вищому медичному навчальному закладі. Найбільш перспективними, 3 нашої точки зору, шляхами вирішення постав- лених завдань у навчально-виховному процесі вищого медичного навчального закладу має стати впровадження спеціально розроблених курсів, застосування сучасних тренінгових технологій. Таким чином, припускаємо, що систематизовані заняття, спрямовані на розвиток психологічних особливостей професійної компетентності майбутнього лікаря, допоможуть у формуванні психологічної готовності до професійної діяльності.

Мета статті: продемонструвати основні аспекти розвитку психологічної готовності майбутнього лікаря до професійної діяльності в процесі фахової підготовки у вищому медичному навчальному закладі.

\section{Виклад основного матеріалу дослі-} дження. Відповідно до мети та завдань дослідження нами було проаналізовано наукові роботи вітчизняних та зарубіжних дослідників, присвячених проблемам готовності до дії, професійної готовності, психологічної готовності до праці, психологічним вимогам до особистості лікаря.

Проведений аналіз дозволив визначити, що психологічна готовність до професійної діяльності являє собою складне інтегративне утворення, що одночасне відображає і рівень розвитку професійно важливих якостей та здібностей майбутнього спеціаліста, і особливості його відношення до обраної професійної діяльності. В структурі психологічної готовності до діяльності виділяються: операційнопрофесійний компонент, емоційно- 
ідентифікаційний компонент, соціальнопсихологічний. Саме таке модель готовності найбільш вичерпно синтезує в собі і класичні, й новітні наукові ідеї щодо психологічної готовності до професійної діяльності. Було визначено, що розвиток психологічної готовності до професійної діяльності становить невід`ємну частину особистісного розвитку людини, триває все життя та має стадіальний характер. Активний етап формування психологічної готовності включає в себе такі стадії: вибір професії, вступ у навчання, адаптація до навчання, адаптація до професійної діяльності. Саме на цих стадіях, на нашу думку, відбуваються найбільш значущі особистісні зміни, що обумовлюють напрямок та успішність розвитку психологічної готовності майбутнього фахівця до професійної діяльності.

На основі вивчення вимог до професії лікаря та уточнення професійно важливих якостей лікарів нами було сформовано модель психологічної готовності майбутнього лікаря до професійної діяльності. Виділено такі компоненти: професійно-інтелектуальний, комунікативний, емоційно-вольовий, моральний, динамічний, нервово-психічний. Визначна структура була покладена в основу процедури діагностики, що представлена у попередніх працях.

Метод експертних оцінок дозволив сформувати перелік факторів, що на думку професійних лікарів, визначають готовність медика-початківця до професійної діяльності.
Лікарі віднесли до найбільш суттєвих факторів: професійно-інтелектуальні якості, вольові якості, емоційну стабільність, самоконтроль, комунікативні якості, емпатію, моральноетичні якості, гнучкість, динамізм особистості. Порівняння визначених факторів з компонентами авторської моделі психологічної готовності майбутніх лікарів показало їх повне змістовне співпадіння. Також первинне дослідження показало, що професійні лікарі вважають, що студенти-медики не володіють достатнім рівнем готовності до професійної діяльності. 3 метою перевірки цих переконань нами було сформовано вибірку дослідження та підібрано психодіагностичні методики, що дозволяють діагностувати рівень розвитку всіх компонентів авторської моделі психологічної готовності до професійної діяльності майбутніх медиків.

Проведений статистичний аналіз даних дозволив нам визначити ряд особливостей розвитку психологічної готовності до професійної діяльності на різних етапах професійного становлення. При цьому, психологічні особливості та переживання студентів-медиків першого курсу майже цілковито обумовлюється процесом адаптації до навчання у медичному виші. Студентам цієї групи притаманні низькій рівень прояву інтелекту, волі та уваги, комунікативних та організаційних здібностей. Вони демонструють ознаки емоційної нестійкості, підвищеної тривожності, замкнутості, консервативності. Їхні нервові процесу відріз- 


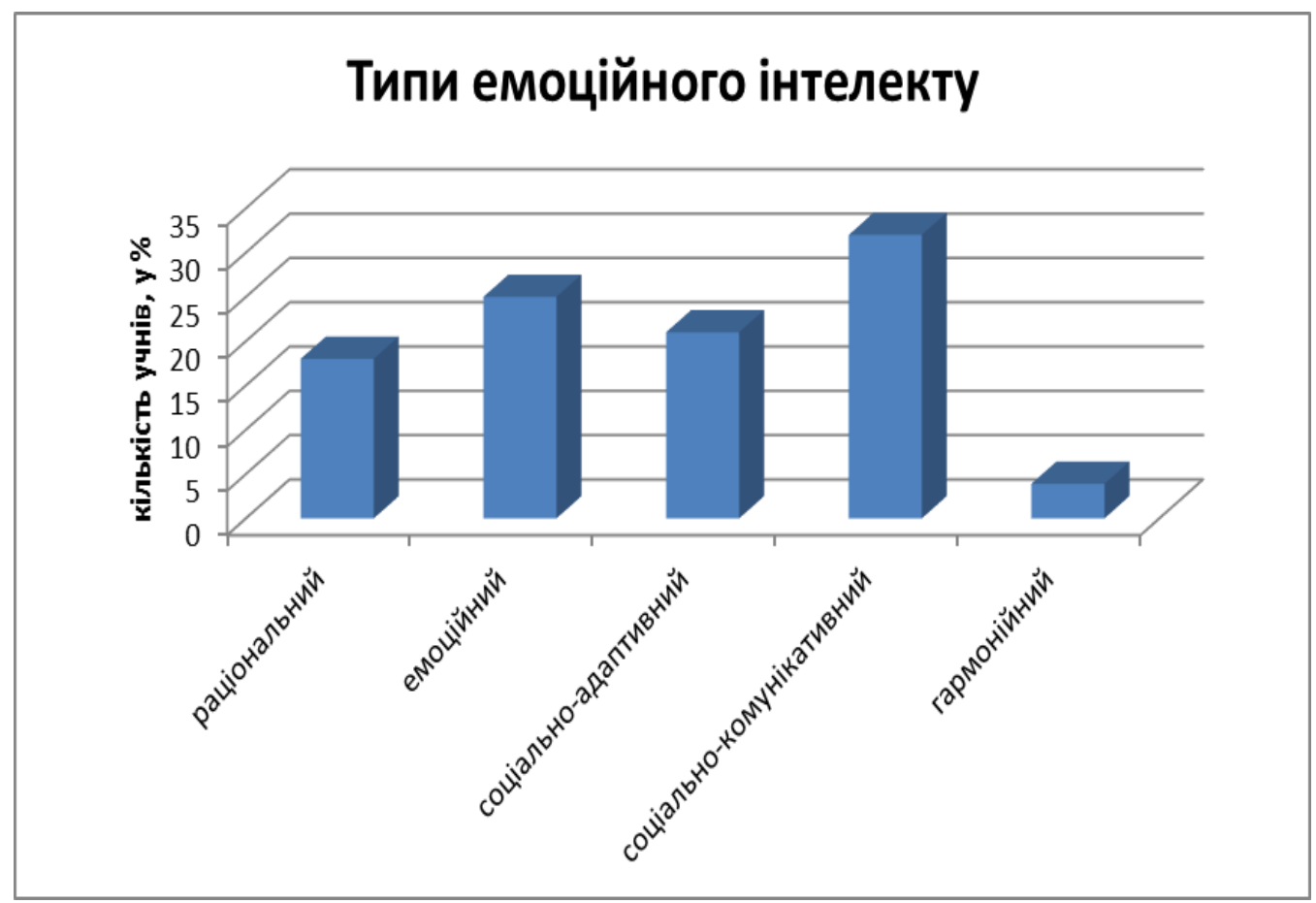

\section{Рис. 1. Типи емоційного інтелекту молодших школярів (за результатами діагностики рівня розвитку його структурних компонентів)}

няються ригідністю з переважанням процесів гальмування. Вони демонструють підвищений рівень конформізму та підпорядкування.

Ситуація розвитку психологічної готовності до професійної діяльності виглядає більш стабільною і врівноваженою в групі студентів третього курсу. Студенти цієї групи демонструють високу впевненість у власних силах, адекватність самооцінки, розвинену уяву, емоційну експресивність і розслабленість. На відміну від першокурсників вони готові до відстоювання власної думки і прояву ситуативної домінантності. Разом 3 тим прояв інтелекту та організаційних навичок залишається на досить невисокому рівні.
Магістранти та інтерни відрізняються суттєвою зібраністю та зосередженістю на вступі в самостійну професійну діяльність. В професійному плані вони демонструють практичність та консерватизм, високий рівень інтелекту. В міжособистісному плані спостерігається товариськість, дипломатичність, готовність до підпорядкування. Серед негативних психологічних явищ переважає підвищена тривожність.

Ситуація розвитку викладачівклініцистів поєднує у собі дві основні тенденції: високий професіоналізм та ознаки емоційного вигоряння. 3 одного боку, ми спостерігаємо, що саме в групі викладачів-клініцистів 
визначено найвищий рівень інтелекту, адекватної самооцінки, комунікативних та організаційних навичок, переважання процесів збудження, висока рухливість нервових процесів, високий рівень емпатії та чутливості. 3 іншого боку не можна не відзначити підвищену міжособистісну тривожність, недостатність процесів гальмування, надмірну прямолінійність, емоційну стриманість, схильність до радикалізму.

Виходячи з теоретичного аналізу зазначеної проблеми та емпіричного дослідження, зважаючи на те, що одним із завдань нашого дослідження була розробка програми формування психологічної готовності майбутнього лікаря в процесі професійної підготовки, спробуємо зосередити увагу на власному досвіді формування цієї якості у студентів. Підкреслимо, що основною метою створення програми формування психологічної готовності майбутнього лікаря до професійної діяльності була необхідність у підготовці кваліфікованих фахівців у галузі медицини з високим рівнем розвитку професійних якостей.

Особливого значення у формуванні психологічної готовності в період професійного навчання у вищому медичному навчальному закладі набуває наявність у студентів професійно важливих якостей особистості, що відповідають вимогам професії, та переважання внутрішньої мотивації професійнонавчальної діяльності.

Професійно важливими якостями для формування психологічної готовності майбутніх лікарів до професійної діяльності, на нашу думку, можна вважати позитивне ставлення до обраної професії, усвідомлення та розуміння власних емоцій і почуттів, управління емоціями, несхильність до афектів і швидкої немотивованої зміни настрою, розвинена емпатія.

Для формування психологічної готовності студентів-медиків до професійної діяльності необхідне практичне розв'язання існуючого істотного протиріччя між високим рівнем вимог до професійно важливих якостей майбутніх лікарів і недостатньою розробленістю психолого-педагогічного супроводу їх розвитку під час навчання у вищому медичному навчальному закладі.

Спираючись на теоретично обгрунтовані психологічні особливості формування психологічної готовності майбутнього лікаря до професійної діяльності, а також виходячи 3 результатів дослідження, ми визначили такі основні напрямки подальшої методичної роботи: 1) розширення і поглиблення професійно важливих знань майбутніх лікарів, що $є$ основою когнітивного компонента психологічної готовності до майбутньої професійної діяльності; 2) з метою цілеспрямованого розвитку психологічної готовності майбутнього лікаря до професійної діяльності включити у процес професійної підготовки майбутніх лікарів спеціальні (вибіркові) курси «Психологія професійної діяльності лікаря», 
«Психологічна готовність до професійної дія-

Охарактеризуємо основні напрямки льності», «Практикум психологічної готовносметодичної роботи з формування психологіч-

Кількісні результати дослідження рівня розвитку емоційного інтелекту в молодших школярів за допомогою опитувальника «ЕмІн» Д.В. Люсіна

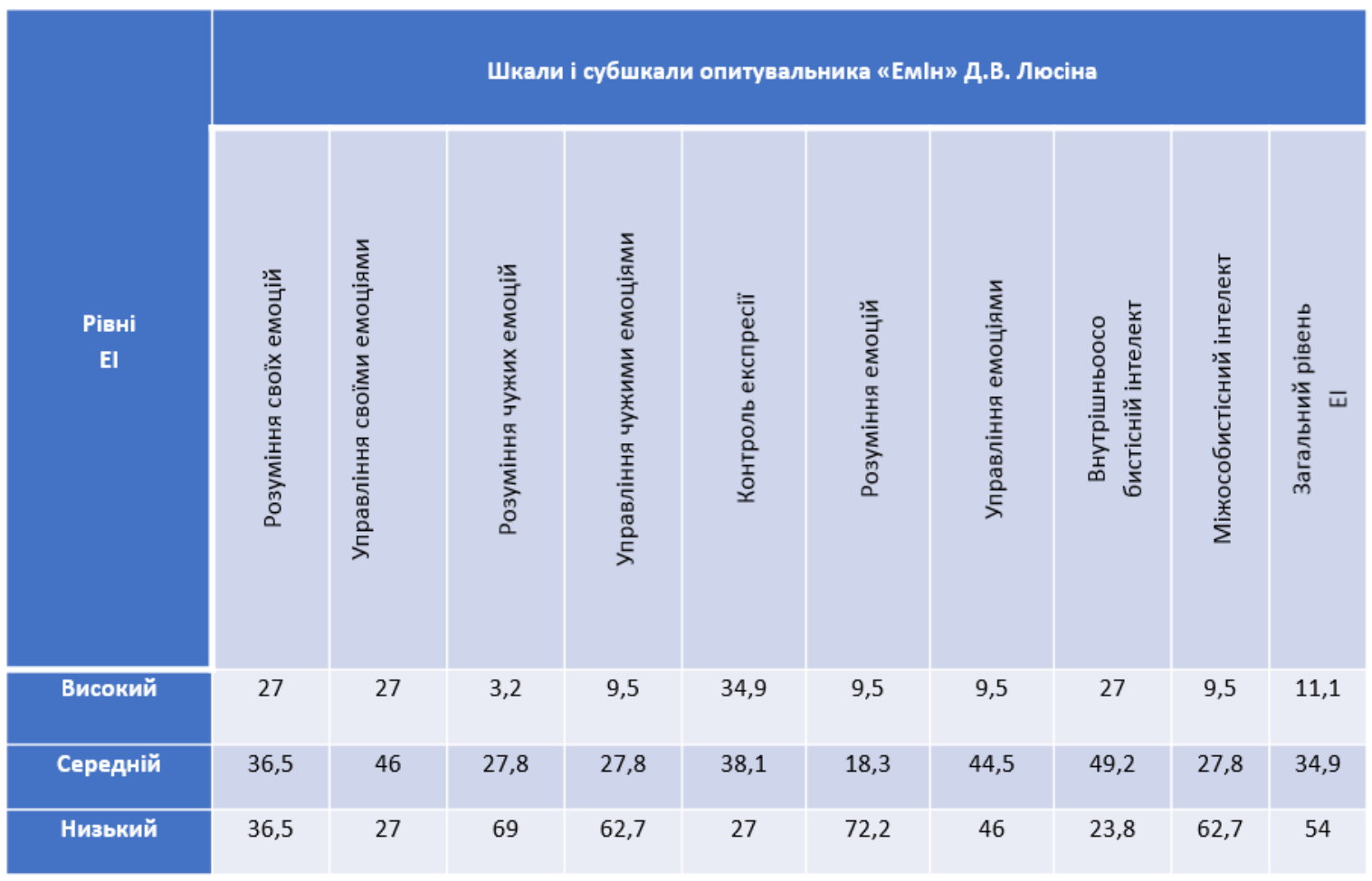

ті до професійної діяльності», а також курс тренінгової форми «Формування професійної компетентності майбутнього лікаря» та «Практикум формування професійних навичок», які передбачали б поєднання теоретичних і практичних занять; 3) розробка моделей індивідуальної педагогічної взаємодії зі студентами на основі діагностики розвитку їхньої професійної компетентності; 4) стимулювання процесу самовиховання майбутніх лікарів шляхом включення студентів у ситуації психологічно обгрунтованого пізнання (практична діяльність, інтернатура). ної готовності майбутнього лікаря до професійної діяльності.

Важлива роль має відводитись навчальним курсам, провідна мета вивчення яких підготовка майбутніх лікарів до здійснення професійної взаємодії; розвиток у студентів уявлення про психологічну готовність та іiі основні компоненти, а також необхідні особистісно-професійні якості, що впливають на іiі розвиток.

Оскільки, як і в будь-якому іншому аспекті розвитку особистості майбутнього фахівця, його пізнавальна активність і самостійна 
діяльність при засвоєнні основ психологічної готовності відіграє важливу роль, тому ми прагнули перетворити позицію студента як об'єкта навчання у позицію його головного суб'єкта, тобто ініціатора, регулятора й активного учасника цього процесу.

На формування психологічної готовності до майбутньої професійної діяльності, на наш погляд, впливає не лише зміст навчального матеріалу, але й інші фактори: форми і методи навчання, взаємостосунки між учасниками навчально-виховного процесу, психологічна атмосфера занять тощо.

Традиційними формами представлення матеріалу є: лекція, в якій переважає односторонній канал передачі інформації і яка забезпечує формування когнітивно-змістовного компоненту психологічної готовності майбутнього лікаря до професійної взаємодії, а також активізує мотиваційно-ціннісний компонент.

Розроблений та впроваджений «Практикум формування психологічної готовності майбутнього лікаря до професійної діяльності» передбачає застосування отриманих знань, формування вмінь та навичок професійної лікувальної взаємодії, створення спеціальних умов, а також двостороннього інформаційного зв'язку. Практикум спрямований на активізацію основних компонентів психологічної готовності (когнітивно-смислового, мотиваційно-ціннісного, операційного та рефлексійного). Під час проведення практичних занять слід поєднувати індивідуальні та групові форми роботи. Групові форми навчання дають можливість поєднати процеси сприймання i засвоєння, що сприяє підвищенню рівня компетентності і глибини знань, формуванню умінь застосовувати ці знання у конкретних професійних ситуаціях. В ході практикуму відбувається моделювання ситуації лікувальної взаємодії, формуються вміння і навички професійної взаємодії в різних ситуаціях спілкування. Зміст практичних занять спрямований на відпрацювання професійних вмінь та навичок взаємодії. Доречно, на наш погляд, використовувати елементи психодіагностики, самопрезентацію, групові дискусії, психотренінгові технології, ділові ігри тощо. Все це дозволить показати студентам важливість психологічної готовності до майбутньої професійної діяльності. Крім цього студенти набувають навичок роботи з тестами та методиками діагностиками та аналізу власних індивідуальних особливостей тощо.

Запропонована нами програма вивчення навчальної дисципліни «Психологія діяльності медичного працівника» складена відповідно до освітньо-професійної програми та освітньо-кваліфікаційної характеристики підготовки спеціалістів кваліфікації «лікар», для спеціальностей «Медицина» та «Медична психологія». Метою викладання дисципліни «Психологія діяльності медичного працівника» є: формування зрілої особистості та професійної ідентичності фахівця лікаря, медичного психолога; розвиток професійних компе- 
тентностей майбутнього лікаря; формування психологічної готовності до майбутньої професійної діяльності, власного професійного стилю; створення умов для усвідомлення фахівцем своїх власних професійних можливостей; профілактика синдрому «професійного вигорання» фахівця; усвідомлення студентами необхідності турботи про власне фізичне та психологічне здоров'я; формування у майбутніх фахівців-медичних психологів систематизованих уявлень, теоретичних знань та практичних вмінь, які дозволять адекватно і ефективно застосовувати отримані знання в подальшій професійній діяльності.

Основними завданнями вивчення дисципліни «Психологія діяльності медичного працівника» є наступні: сприяння розвитку професійної ідентичності, професійних якостей та компетенцій лікаря, медичного психолога; становлення образу ефективного професійного майбутнього; побудова адекватного професійного образу «Я»; актуалізація професійних та особистих ресурсів; розвиток психологічної готовності до майбутньої професійної діяльності; формування професійної та інших компетентностей та гідності; розвиток професійної рефлексії.

Наступним кроком у професійній підготовці студентів в рамках програми формування психологічної готовності майбутнього лікаря до професійної діяльності здійснюється завдяки спеціально організованого тренінгу, як активного метода.
Аналізуючи особливості тренінгу, можна підкреслити, що ця сучасна освітня технологія дозволяє не лише підвищити професійну компетентність, а й сприяє формуванню психологічної готовності фахівця до майбутньої професійної діяльності в цілому. Використання саме такої форми навчання дозволяє розвивати у майбутніх лікарів вміння розуміти стосунки, установки, психологічні проблеми, внутрішні конфлікти, а також сприяє більш глибокому розумінню власної особистості, своїх мотивів, інтересів, бажань, потреб тощо.

Важливе значення у формуванні психологічної готовності майбутнього лікаря до професійної діяльності має і безпосередня практична діяльність майбутнього фахівця. Лікарям необхідно вміти налагоджувати контакти, підтримувати стосунки, активно взаємодіяти, досягати взаєморозуміння в процесі виконання професійних обов 'язків, розбиратися в поведінці людей, розуміти їх емоційні стани, потреби, надавати емоційну підтримку, емоційно адекватно реагувати на гнів, сум, невдоволення, критику з боку інших, зберігати рівновагу в конфліктних ситуаціях, знаходити індивідуальні підходи, тобто бути підготовленими до ефективної комунікації та емоційно розумної поведінки.

Під час навчання в інтернатурі у майбутніх лікарів формуються вміння самостійно розв'язувати практичні завдання, виходячи із загальних принципів, опанованих студентами у процесі теоретичної підготовки, із врахуван- 
ням спеціалізації, конкретних умов та ситуацій професійної діяльності.

Важливо також зазначити, що під час навчання в інтернатурі лікарі мають справу з цілісним процесом майбутньої діяльності у всій iï різноманітності і складності, а не з окремими навчальними завданнями, які спеціально добираються і аналізуються у навчальних аудиторіях на додипломному етапі підготовки у ВМНЗ. Завдання, що доводиться вирішувати майбутньому лікарю в інтернатурі це вже реальні практичні завдання, а не моделі практичних ситуацій, які використовуються 3 суто навчальною метою. Це відпрацювання професійних навичок в безпосередній практичній діяльності.

Яким же чином слід організувати процес формування психологічної готовності майбутнього лікаря до професійної діяльності в умовах навчання в інтернатурі? На наш погляд, необхідно активно включати навчальні завдання у реальний процес практичної діяльності інтернів, з глибоким аналізом ситуацій лікувальної взаємодії, організацією спостережень інтернів за досвідченими лікарями, розв'язанням завдань проективного характеру, плануванням системи лікувальних впливів, визначенням методів своєї діяльності, здатністю встановлювати емоційний контакт тощо. В процесі обговорення професійних ситуацій слід докладно розглядати найбільш вдалі і невдалі емоціогенні ситуації, причиннонаслідкові зв'язки, які цьому сприяли, прово- дити діагностування особливостей емоційної сфери окремих пацієнтів. Бажано, щоб кожний інтерн вів щоденник психологічних спостережень, виявляв власні досягнення, помилки, невдачі, здійснював пошук можливих варіантів покрашення професійної діяльності, визначав бажані зміни і перспективи у формуванні власної професійної компетентності та психологічної готовності.

Нами запропонований «Практикум формування професійних навичок», в якому представлені розроблені спеціальні завдання, спрямовані на аналіз власних важливих компонентів професійної компетентності у практичній професійній діяльності. Він передбачає ознайомлення студентів 3 психологічними основами професійної діяльності лікаря. Основними завданнями практикуму є формування у майбутніх лікарів знань про психологічну готовність до професійної діяльності та вибору фаху як складного психологічного утворення, що передбачає певний рівень розвитку особистості фахівця в цілому, а також здійснення професійної діагностики, засвоєння студентами основ наукової організації праці професіонала. Практикум містить ряд відомих методик психологічного аналізу різних аспектів професійної діяльності. Контрольні запитання спрямовані на активізацію знань студентів, їх вмінь та мотивації формування психологічної готовності до майбутньої професійної діяльності.

Таким чином, завдання які мають вико- 
нувати лікарі-інтерни у ході практичної діяльності, сприятимуть актуалізації, узагальненню і поглибленню теоретичних знань щодо засад професійної компетентності, корекції, розвитку і вдосконаленню сформованих вмінь і навичок у професійній сфері.

В цілому, весь процес формування психологічної готовності майбутніх лікарів до професійної діяльності в межах пропонованої нами програми поділений на декілька етапів. Пізнання самого себе - перший етап розвитку психологічної готовності. Цілями даного етапу є: розвиток уміння усвідомлювати свої наміри, бажання; навчитися уважно ставитися до своїх почуттів; розвиток вміння аналізувати та висловлювати свої думки. Даний етап спрямований на розвиток когнітивного компоненту психологічної готовності.

Рефлексія - другий етап розвитку професійної готовності. Це процес дзеркального взаємовідображення суб'єктів, змістом якого є відтворення особливостей іншої людини. Крім самопізнання та саморозуміння, рефлексія включає такі процеси як розуміння й оцінка іншого. Завдяки рефлексії як механізму формування психологічної готовності до майбутньої професійної діяльності досягається співвіднесення своєї свідомості, цінностей, думок, вчинків і станів з цінностями, думками, вчинками, станами інших людей, що є запорукою продуктивності діяльності лікаря. Даний етап спрямований на розвиток соціального компоненту психологічної готовності.
Керування своїми емоціями та почуттями - третій етап розвитку психологічної готовності до майбутньої професійної діяльності. Цілями даного етапу є: розвиток уміння управляти своїм станом у складних ситуаціях; керувати своїми емоціями і поведінкою; відкрито виражати свої почуття; визначати почуття і емоції партнера; добре розбиратися в емоціях та почуттях інших. Даний етап спрямований в основному на розвиток регулятивного компоненту. На здатність керувати своїми емоціями впливає уміння студентів - майбутніх лікарів визнавати власні емоції та почуття, вміло поводитися з ними в процесі майбутньої професійної діяльності. Вміння контролювати емоційні стани дозволяє використовувати емоції для досягнення поставленої мети.

На четвертому етапі увага приділяється розвитку та вдосконаленню професійної компетентності. Даний етап націлений більшою мірою на розвиток операційного компонента психологічної готовності майбутнього лікаря до майбутньої професійної діяльності.

Висновки. Проведений теоретичний аналіз дозволив уточнити, що психологічна готовність до професійної діяльності являє собою складне інтегративне утворення, що одночасне відображає і рівень розвитку професійно важливих якостей та здібностей майбутнього спеціаліста, і особливості його відношення до обраної професійної діяльності. Психологічна готовність до професійної дія- 
льності розглядається як комплекс взаємопов'язаних та взаємозумовлених психологічних якостей, наявність яких у майбутнього лікаря має сприяти успішній професійній діяльності у галузі медицини та взаємодії всіх іiї суб'єктів. В структурі психологічної готовності до діяльності в самому загальному вигляді доцільно виділяти: особистісний, інтелектуальний (когнітивний). Узагальнення уявлень представників різних підходів щодо структури психологічної готовності до професійної діяльності дозволило визначити такі їі компоненти як: операційно - професійний, емоційно ідентифікаційний, соціально - психологічний компонент.

Уточнення методологічних та методичних підходів дозволило встановити, що психологічна готовність до професійної діяльності являє собою невід'ємну частину особистісного розвитку людини, триває все життя та має стадіальний характер. Активний етап формування психологічної готовності включає в себе такі стадії: вибір професії, вступ у навчання, адаптація до навчання, адаптація до професійної діяльності. Саме на цих стадіях відбуваються найбільш значущі особистісні зміни, що обумовлюють напрямок та успішність розвитку психологічної готовності майбутнього фахівця до професійної діяльності. Аналіз підходів до визначення структури психологічної готовності в загальному вигляді та досліджень, присвячених вивченню психологічно важливих якостей лікарів, дав нам змогу роз- робити авторську структуру психологічної готовності лікаря, що включила в себе шість взаємопов'язаних компонентів: професійноінтелектуальний, комунікативний, вольовий, моральний, динамічний, нервово-психічний. Визначені за допомогою теоретичного аналізу компоненти психологічної готовності майже повністю ідентичні за змістом факторам готовності до діяльності, які були визначені професійними лікарями в ході опитування. Розроблена структура психологічної готовності була покладена в основу процедури діагностики.

3 урахуванням вимог професійної діяльності до особистості лікаря та компонентів авторської моделі психологічної готовності до професійної діяльності майбутніх лікарів було розроблено процедуру дослідження, що здійснювалася 3 використанням верифікованих психодіагностичних методик. Дослідження дозволило визначити характерні особливості розвитку компонентів психологічної готовності до професійної діяльності, що притаманні медикам на різних стадіях професійної готовності. Так, На першій стадії, що була названа «вступ в навчання» (перший курс) студенти демонструють понижений рівень волі, уваги, інтелекту, комунікативних та організаційних здібностей. Вони зіштовхуються з необхідністю одночасної адаптації і до освоєння профеciï, i до умов навчання у вищому медичному навчальному закладі. Результатом є підвищений рівень тривожності та емоційної нестабільності. Ведучими факторами розвитку в цей 
період $є$ : вступ в навчання, засвоєння професійних норм, спрямованість на спілкування, затвердження власної індивідуальності, чутливість. На другій стадії, що отримала назву «адаптація до навчання» (третій курс), студенти-медики демонструють високу впевненість у власних силах, адекватність самооцінки, розвинену уяву, емоційну експресивність і розслабленість. На відміну від першокурсників вони готові до відстоювання власної думки і прояву ситуативної домінантності. Фактори розвитку на цьому етапі: розвиток емпатії, впевненість у собі, готовність до співпраці, врівноваженість та контроль емоційної експресії. На третій стадії - «адаптація до професійної діяльності» (магістранти, інтерни) майбутні лікарі характеризуються зібраністю та зосередженістю на вступі в самостійну професійну діяльність. В професійному плані вони демонструють практичність та консерватизм, високий рівень інтелекту. В міжособистісному плані спостерігається товариськість, дипломатичність, готовність до підпорядкування. Ведучі фактори розвитку: вступ в професійну діяльність, нормативність поведінки, зосередженість та впевненість у собі, конструктивне спілкування, емоційна чутливість.

Дослідження психологічного профілю викладачів-клініцистів показало, що йому притаманні ознаки високого професіоналізму та елементів емоційного вигоряння. Ведучі фактори розвитку: емпатія, дипломатичність, домінантність та новаторство, міжособистісна тривожність, консервативність у спілкуванні.

Емоційна готовність майбутніх лікарів до професійної діяльності як стійке системне психологічне утворення в структурі емоційної сфери особистості майбутнього фахівця виражає певний рівень емоційної зрілості особистості, базується на розвиненій емоційній компетентності та забезпечує ефективну лікувальну взаємодію. Структурними компонентами емоційної готовності лікаря до майбутньої професійної діяльності є усвідомлення власних емоцій, керування емоціями, несхильність до афектів і швидкої немотивованої зміни настрою, розвинена емпатія, тощо. Особливого значення в успішності формування емоційної готовності до майбутньої професійної діяльності в період професійного навчання у вищому медичному навчальному закладі набуває наявність у студентів професійно важливих якостей особистості, що відповідають вимогам професії лікаря, в тому числі у сфері емоцій.

Спираючись на теоретично обгрунтовані психологічні особливості формування психологічної готовності майбутнього лікаря до професійної діяльності, а також виходячи 3 результатів емпіричного дослідження, було визначено основні напрямки методичної роботи.

Нові перспективи розвитку даної проблематики полягають, на наш погляд, у подальших дослідженнях, присвячених шляхам 
розвитку психологічної готовності майбутніх лікарів до професійної діяльності з застосуванням методів та засобів активного навчання.

\section{Перелік використаних джерел:}

1. Борисюк А. С. Психологічні особливості формування професійних якостей майбутнього медичного психолога : дис. ... канд. псих. наук : 19.00.07 / А.С. Борисюк. Івано-Франківськ, 2004. - 229 с.

2. Гордієнко B. I. Розвиток особистості в процесі професіоналізації : професіогенез особистості / В. І. Гордієнко // Психологія праці та професійної підготовки особистості : навч. посібник / за ред. П. С. Перепелиці, В. В. Рибалки. - Хмельницький : Вид-во ТУП, 2001. - С. 4867.

3. Задорожна О. М. Готовність до свідомого професійного вибору як соціально-психологічної проблеми / О.М. Задорожна // Психологічні перспективи / Східноєвроп. нац. ун-т ім. Лесі Українки, Ін-т соц. та політ. психології АПН України. - Луцьк, 2013. - Вип. 21. - С. 58-70.

4. Лазуренко О. О. Концепція формування емоційної компетентності на різних етапах професійної підготовки лікаря /О. О. Лазуренко // Науковий вісник Херсонського державного університету. Серія: Психологічні науки. - Випуск 3. - Херсон, 2015. - С. 113-117.

5. Лазуренко О. О., Тамакова Т. А. Психологія професійної діяльності в контексті методологічних проблем фахової підготовки лікарів-психологів у ВМНЗ України. / О.О. Лазуренко, Т.А. Тамакова // Матеріали III міжнародної науково-практичної конференції «Медична психологія: здобутки, розвиток та перспективи». - К., 2014. - С.55-58.

6. Лазуренко О. О., Сміла Н. В. General description of emotional education students in medical university of Ukraine / О.О. Лазуренко, Н. В. Сміла // Мат-ли Всеукр. навч.-наук. конф. 3 міжнар. участю «Досягнення і перспективи впровадження КМСОНП у ВМНЗ України». -
Ч. І. - Тернопіль, 15-16 травня 2014. - С. 420-422.

7. Малхазов О. Р. Психологія праці / О.Р. Малхазов Навч. посіб. - К.: Центр учбової літератури, 2010. - 208 c.

8. Максименко С. Д. Генеза здійснення особистості / Максименко С.Д. - К.: ТОВ «КММ», 2006. - 240 с.

9. Мариенюк І. П. Особливості формування професійно ціннісних орієнтацій студентів університету / I. П. Марценюк // Науковий вісник Волинського національного університету ім. Лесі Українки. Педагогічні науки / Волин. нац. ун-т ім. Лесі Українки - Луцьк. - 2012. - № 8. - C. 67-71.

10. Мельник $A$. Деякі питання професійної підготовки фахівців медичного профілю у контексті сучасних інтеграційних процесів / А. Мельник // Вісн. Львів. ун-ту. Сер. «Педагогіка». - 2010. - Вип. 26. - С. 34-40.

11. Сміла Н. В. Психологічна готовність майбутніх лікарів: які властивості особистості повинні бути сформовані?/ Н.В. Сміла // Матеріали VIII міжнародної науково-практичної конференції “Наука і освіта 2005”. Том 52: Психологія. - Дніпропетровськ: Наука і освіта, 2005. - C.33-34.

12. Сміла Н. В. Проблема формування та розвитку психологічної готовності майбутніх лікарів. / Н.В. Сміла// Формування сучасної концепції викладання природничих дисциплін в медичних освітніх закладах: Збірка тез. - Харків, 2005. - С. 88-89.

13. Сміла Н. В. Значення діагностики психологічної готовності майбутніх лікарів для підготовки висококваліфікованих медичних кадрів. / Н.В. Сміла. // Збірка наукових праць I Національного Конгресу лікарів внутрішньої медицини. - Київ, 2005. - С.108-109.

14. Сміла Н. В. Методи дослідження психологічної готовності студентів медичних ВУЗів до майбутньої професійної діяльності/ Н.В. Сміла. // Матеріали IV міжнародної науково-практичної конференції „Динаміка наукових досліджень 2005”. - Том 57. Психологія та соціологія. - Дніпропетровськ: Наука і освіта. - 2005. - С. 28 -29 .

15. Сміла Н. В. Вивчення психологічної готовності сту- 
дентів-медиків третього курсу до майбутньої професійної діяльності. / Н.В. Сміла. // Актуальні проблеми психології. - Том V. Психофізіологія. Психологія праці. Експериментальна психологія. - Випуск 7. - Київ, 2007. - C.258-263.

16. Lazurenko O., Smila N. Psychological and Pedagogical Principles of Students' Emotional Sphere formation in the Process of Professional Training and Development.// Journal of Psychological Sciences. - Vol.2. - No.3. - 2016. PP. 124-129.

\section{References (Transliteration):}

1. Borisyuk A. S. PsihologIchnI osoblivostI formuvannya profesIynih yakostey maybutnogo medichnogo psihologa : dis. ... kand. psih. nauk : 19.00.07 / A.S. Borisyuk. - Ivano -FrankIvsk, 2004. - $229 \mathrm{~s}$.

2. GordIenko V. I. Rozvitok osobistostI $\mathrm{v}$ protsesI profesIonalIzatsIYi : profesIogenez osobistostI / V. I. GordIEnko // PsihologIya pratsI ta profesIynoYi pIdgotovki osobistostI : navch. posIbnik / za red. P. S. PerepelitsI, V. V. Ribalki. - Hmelnitskiy : Vid-vo TUP, 2001. - S. 48-67. 3. Zadorozhna O. M. GotovnIst do svIdomogo profesIynogo viboru yak sotsIalno-psihologIchnoYi problemi / O.M. Zadorozhna // PsihologIchnI perspektivi / ShIdnoEvrop. nats. un-t Im. LesI UkraYinki, In-t sots. ta polIt. psihologIYi APN UkraYini. - Lutsk, 2013. - Vip. 21. - S. 58-70.

4. Lazurenko O. O. KontseptsIya formuvannya emotsIynoYi kompetentnostI na rIznih etapah profesIynoYi pIdgotovki lIkarya /O. O. Lazurenko // Naukoviy vIsnik Hersonskogo derzhavnogo unIversitetu. SerIya: PsihologIchnI nauki. - Vipusk 3. - Herson, 2015. - S. 113117.

5. Lazurenko O. O., Tamakova T.A. PsihologIya profesIynoYi dIyalnostI $\mathrm{v}$ kontekstI metodologIchnih problem fahovoYi pIdgotovki lIkarIv-psihologIv u VMNZ UkraYini. / O.O. Lazurenko, T.A. Tamakova // MaterIali III mIzhnarodnoYi naukovo-praktichnoYi konferentsIYi
«Medichna psihologIya: zdobutki, rozvitok ta perspektivi». - K., 2014. - S.55-58.

6. Lazurenko O. O., SmIla N.V. General description of emotional education students in medical university of Ukraine / O.O. Lazurenko, N. V. SmIla // Mat-li Vseukr. navch.-nauk. konf. z mIzhnar. uchastyu «Dosyagnennya I perspektivi vprovadzhennya KMSONP u VMNZ UkraYini». - Ch. I. - TernopIl, 15-16 travnya 2014. - S. 420-422.

7. Malhazov O. R. PsihologIya pratsI / O.R. Malhazov Navch. posIb. - K.: Tsentr uchbovoYi IIteraturi, 2010. $208 \mathrm{~s}$.

8. Maksimenko S. D. Geneza zdIysnennya osobistostI / Maksimenko S.D. - K.: TOV «KMM», 2006. - 240 s.

9. Martsenyuk I. P. OsoblivostI formuvannya profesIyno tsInnIsnih orIEntatsIy studentIv unIversitetu / I. P. Martsenyuk // Naukoviy vIsnik Volinskogo natsIonalnogo unIversitetu Im. LesI UkraYinki. PedagogIchnI nauki / Volin. nats. un-t Im. LesI UkraYinki - Lutsk. - 2012. - \# 8: - S. 67-71.

10. Melnik $A$. DeyakI pitannya profesIynoYi pIdgotovki fahIvtsIv medichnogo profIlyu u kontekstI cuchasnih IntegratsIynih protsesIv / A. Melnik // VIsn. LvIv. un-tu. Ser. «PedagogIka». - 2010. - Vip. 26. - S. 34-40.

11. Smila N. V. PsihologIchna gotovnIst maybutnIh IIkarIv: yakI vlastivostI osobistostI povinnI buti sformovanI?/ N.V. SmIla // MaterIali VIII mIzhnarodnoYi naukovopraktichnoYi konferentsIYi "Nauka I osvIta 2005". - Tom 52: PsihologIya. - DnIpropetrovsk: Nauka I osvIta, 2005. S.33-34.

12. Smila N. $V$. Problema formuvannya ta rozvitku psihologIchnoYi gotovnostI maybutnIh lIkarIv. / N.V. SmIla// Formuvannya suchasnoYi kontseptsIYi vikladannya prirodnichih distsiplIn $\mathrm{v}$ medichnih osvItnIh zakladah: ZbIrka tez. - HarkIv, 2005. - S. 88-89.

13. Smila $N$. $V$. Znachennya dIagnostiki psihologIchnoYi gotovnostI maybutnIh IIkarIv dlya pIdgotovki visokokvalIfIkovanih medichnih kadrIv. / N.V. SmIla. // ZbIrka naukovih prats I NatsIonalnogo Kongresu IIkarIv vnutrIshnoYi meditsini. - KiYiv, 2005. - S.108-109. 
14. Smila $N . \quad V$. Metodi doslidzhennya psihologIchnoyi gotovnostI studentIv medichnih VUZIv do maybutnoyi profesIynoyi dIyalnostI/ N.V. SmIla. // MaterIali IV mIzhnarodnoyi naukovo-praktichnoyi konferentsiyi «Dinamika naukovih doslidzhen 2005». - Tom 57. Psihologiya ta sotsiologiya. - DnIpropetrovsk: Nauka i osvita. - 2005. - S. 28-29.

15. Smila $N . V$. Vivchennya psihologIchnoYi gotovnostI studentIv-medikIv tretogo kursu do maybutnoYi profesIynoYi dIyalnostI. / N.V. SmIla. // AktualnI problemi psihologIYi. - Tom V. PsihofIzIologIya. PsihologIya pratsI. Eksperimentalna psihologIya. - Vipusk 7. - KiYiv, 2007. - S.258-263.

16. Lazurenko O., Smila N. Psychological and Pedagogical Principles of Student's Emotional Sphere formation in the Process of Professional Training and Development.// Journal of Psychological Sciences. - Vol.2. - No.3. - 2016. PP. 124-129.

\section{Smila Natalya}

Scientific correspondent, laboratory of psychology training Institute of psychology named after G. S. Kostiuk NAPS of Ukraine, Kyiv (Ukraine)

\section{Lazurenko Olena}

Senior Lecturer, Department of General and Medical Psychology and Pedagogy Bogomolets National Medical University, Kyiv (Ukraine)

\section{EXPERIENCE OF PSYCHOLOGICAL READINESS FORMATION OF FUTURE DOCTORS FOR THE PROFESSIONAL ACTIVITIES}

\section{ABSTRACT}

The problem of the formation of professional competence of future doctors is one of the most important in the field of professional medical education. The article studies main properties of psychological readiness formation of future doctors for the professional activities. The article is focused on theoretical and practical bases of the diagnostics of psychological readiness of future doctors for professional activities based on components and stages of its development.

The paper theoretically grounded basic stages of development of psychological readiness for professional activities with account of age features of students. In particular highlighted the steps of psychological readiness: choosing a career, joining the study, adaptation to study, adaptation to professional activities. The structure of doctor's psychological readiness for professional activities included the following six components: professional and intellectual, communicative, emotional, volitional, moral, dynamic, nervous and mental. The content and nature of components is confirmed with the use of expert evaluation. Main aspects of future doctors' professional training at higher medical educational institutions are also described.

Using empirical research the features and factors of psychological readiness for professional activity of future doctors were shown. Determined that all components of readiness develop gradually and reach its peak during the process of adaptation to professional activities. After summarizing the results of the factor analysis identified factors of psychological readiness of doctors to the profession at various stages of development. Today, there are available and used a variety of exercises, tasks, seminars, workshops aimed at the development of the professional competence of the student, which can be suggested as an 
additional material in the process of theoretical and practical training of future doctors in higher medical educational establishments. The concept of formation of psychological readiness formation of future doctors for the professional activities is suggested. Prospects and directions for future research were identified.

Key words: professional activity, psychological readiness, professional development of medic competence, personal development, training course

\section{Смелая Наталия Владимировна}

Научный корреспондент лаборатории психологии обучения Института психологии имени Г.С. Костюка НАПН Украины, г. Киев (Украина)

\section{Лазуренко Елена Алексеевна}

Старший преподаватель кафедры общей и медицинской психологии и педагогики Национального медицинского университета имени А.А. Богомольца, г. Киев (Украина)

\section{ОПЫТ ФОРМИРОВАНИЯ ПСИХОЛОГИЧЕСКОЙ ГОТОВНОСТИ БУДУЩЕГО ВРАЧА К ПРОФЕССИОНАЛЬНОЙ ДЕЯТЕЛЬНОСТИ}

Аннотация. Целенаправленное развитие психологической готовности будущего врача означает направленность образования не только на формирование знаний, умений и навыков, но и на многоуровневое развитие индивидуально-психологических свойств, способностей, расширение возможностей применения творчества будущих специалистов в сфере медицины. Недостаточная определен- ность базовых понятий темы исследования, высокая общественная потребность в качественных медицинских кадрах, недостаточность исследования проблемы психологической готовности врача к профессиональной деятельности и критериев ее формирования обусловили актуальность темы исследования.

Согласно цели и задач исследования нами были проанализированы научные работы отечественных и зарубежных исследователей, посвященных проблемам готовности к действию, профессиональной готовности, психологической готовности к труду, психологическим требованиям к личности врача. Было определено, что развитие психологической готовности к профессиональной деятельности составляет неотъемлемую часть личностного развития человека, продолжается всю жизнь и имеет стадиальный характер. Активный этап формирования психологической готовности включает в себя следующие стадии: выбор профессии, вступление в обучении, адаптация к обучению, адаптация к профессиональной деятельности. Именно на этих стадиях, по нашему мнению, происходят наиболее значимые личностные изменения, обусловливающие направление и успешность развития психологической готовности будущего специалиста к профессиональной деятельности. Особое значение в формировании психологической готовности в период профессионального обучения в высшем медицинском учебном заведении приобретает наличие у студентов про- 
фессионально важных качеств личности, отвечающих требованиям профессии, и преобладание внутренней мотивации профессиональноучебной деятельности.

Выделено психолого-педагогические составляющие формирования психологической готовности будущего врача в учебном процессе. Опираясь на теоретически обоснованные психологические особенности формирования психологической готовности будущего врача к профессиональной деятельности, а также исходя из результатов эмпирического исследования, были определены основные направления методической работы. Сделаны выводы и сформированы перспективы дальнейших научных исследований.

Ключевые слова: профессиональная деятельность, психологическая готовность, профессиональное становление врача, профессиональная компетентность, личностное развитие, профессиональная подготовка. 